University of Wollongong

Research Online

Faculty of Law, Humanities and the Arts Papers (Archive)

Faculty of Arts, Social Sciences \& Humanities

$1-1-2015$

Institutional influences on the parameters of criminalisation: parliamentary scrutiny of criminal law bills in New South Wales

Luke J. McNamara

University of Wollongong, lukem@uow.edu.au

Julia Quilter

University of Wollongong, jquilter@uow.edu.au

Follow this and additional works at: https://ro.uow.edu.au/lhapapers

Part of the Arts and Humanities Commons, and the Law Commons

Research Online is the open access institutional repository for the University of Wollongong. For further information contact the UOW Library: research-pubs@uow.edu.au 


\title{
Institutional influences on the parameters of criminalisation: parliamentary scrutiny of criminal law bills in New South Wales
}

\author{
Abstract \\ Within criminalisation scholarship, there has been little engagement with the work of 'real-world' \\ mechanisms for promoting principled law-making, like the activities of parliamentary scrutiny \\ committees. This article reports on an examination of the New South Wales ('NSW') Legislation Review \\ Committee's findings and recommendations in relation to all criminal law bills during the period 2010-12 \\ and assesses the impact of the Committee's recommendations on the passage of bills through the NSW \\ Parliament. It considers whether the potential for scrutiny committees to play an effective role in \\ delineating the legitimate boundaries of criminalisation is realised in practice.

\section{Keywords} \\ scrutiny, parliamentary, criminalisation, parameters, criminal, influences, wales, institutional, law, bills, \\ south

\section{Disciplines} \\ Arts and Humanities | Law

\section{Publication Details} \\ McNamara, L. J. and Quilter, J. (2015). Institutional influences on the parameters of criminalisation: \\ parliamentary scrutiny of criminal law bills in New South Wales. Current Issues in Criminal Justice, 27 (1), \\ 21-40.
}




\title{
Institutional Influences on the Parameters of Criminalisation: Parliamentary Scrutiny of Criminal Law Bills in New South Wales
}

\author{
Luke McNamara* and Julia Quilter $^{\dagger}$
}

\begin{abstract}
Within criminalisation scholarship, there has been little engagement with the work of 'real-world' mechanisms for promoting principled law-making, like the activities of parliamentary scrutiny committees. This article reports on an examination of the New South Wales ('NSW') Legislation Review Committee's findings and recommendations in relation to all criminal law bills during the period 2010-12 and assesses the impact of the Committee's recommendations on the passage of bills through the NSW Parliament. It considers whether the potential for scrutiny committees to play an effective role in delineating the legitimate boundaries of criminalisation is realised in practice.
\end{abstract}

Keywords: criminalisation - criminal law - rights and liberties - pre-enactment scrutiny - parliament - New South Wales

\section{Introduction}

The question of how far legislators should be able to go in employing the criminal law as a public policy tool — that is, as a mechanism for deterring and punishing behaviour that causes harm or generates a risk of harm - has long been a concern to criminal law scholars, legal practitioners and advocates for human rights and civil liberties. Attempts to theorise the boundaries of when criminal law can legitimately be used to address a harm or risk of public concern have proliferated in the academic literature during the last decade (Husak 2008; Duff 2014; Duff et al 2014; Ashworth 2008; Baker 2011; Zedner and Roberts 2012; Ashworth and Zedner 2014).

\footnotetext{
Professor, Legal Intersections Research Centre, School of Law, University of Wollongong NSW 2522 Australia. Email: lukem@uow.edu.au. This article was made possible by a grant under the Legal Intersections Research Centre Small Grants Scheme. Thanks to Jai Clark for excellent research assistance.

$+\quad$ Senior Lecturer, Legal Intersections Research Centre, School of Law, University of Wollongong NSW 2522 Australia. Email: jquilter@uow.edu.au.
} 
Critical criminal law scholars such as Brown (2013) and Lacey (2009) have argued that theorising the legitimate limits of criminal law requires a more robust foundation that draws on historicised and empirical research (McNamara 2015). Lacey (2013:361) has asserted that it should be a priority of contemporary scholarship to:

develop and support an emerging view of criminal law theory as not exclusively a matter of analytical philosophy and doctrinal analysis but also an enterprise whose power to illuminate its terrain is premised on a concern not only with normative questions but also with their institutional and other conditions of existence.

Normative scholarship has been motivated by instances of criminalisation that are regarded as insufficiently respectful of fundamental principles regarding when and how it is appropriate to deploy the state's power to impose criminal punishment and by the volume of criminal offences created. In many common law countries including Australia, the number of criminal offences has been growing rapidly, and the list of activities brought into the category of 'crime' has correspondingly widened (Ashworth 2000). For example, in 2010-11, 1760 offences were created in the United Kingdom (Chalmers and Leverick 2013, 2014) and, in 2008, 302 offences were created in NSW alone (Brown 2015).

One of the criticisms that has been made of criminal law-making is that governments are too willing to use the criminal law 'broadly and casually as a regulatory tool' (Brown 2009:271) and 'in an unprincipled way, as a high visibility quick fix rather than as a carefully considered and designed policy instrument' (McNamara 2015:34). As Hogg and Brown (1998) observed, a key tenet of the prevailing wisdom or 'common sense' on crime prevention is that the solution is to be found in "measures to redress the imbalance that currently favours "criminals" and strengthen the capacity of the criminal justice system to control and suppress crime’ (1998:20).

Criminalisation is a complex phenomenon, and grounded research is required on all of its multiple dimensions, including offence creation and operation (McNamara 2015) and all of the 'sites' where the shape and form of the criminal law is susceptible to influence. As part of a wider program of criminalisation research in which the authors are engaged (Quilter and McNamara 2013; McNamara and Quilter 2015; Brown et al 2015; McNamara 2015; Quilter 2015), ${ }^{1}$ this article takes up the challenge of contributing to a stronger empirical foundation for normative evaluation of the legitimate limits of criminal law-making by examining one such site. Specifically, it focuses on an under-researched institutional component of the public policy formulation and law reform process: the parliamentary scrutiny committee.

This article presents the findings of an analysis of the work of the NSW Legislation Review Committee over a three-year period from 2010 to 2012. Its primary aim is to assess what influence, if any, the Committee has had on the passage (and shape) of criminal law bills considered by the Parliament. ${ }^{2}$

In addition to responding to the identified need for localised and empirical criminalisation research, this article also notes that the role of scrutiny committees, generally, has attracted very little scholarly attention. (For a notable exception, see Byrnes 2009; see also Pratt 2012.) This current research is designed to complement the limited work undertaken to date, with a specific focus on the influence of the NSW Legislation Review Committee on criminal lawmaking.

1 Our work on this article has benefited from the stimulating conversations about criminalisation that we have had with David Brown, Russell Hogg, Heather Douglas, Arlie Loughnan and Alex Steel.

2 One of the authors (McNamara) has previously served as a Legal Adviser to the Legislation Review Committee (2003-07). 
All political environments require authoritative normative frameworks for distinguishing 'good' deployments of criminalisation from 'bad'; for guiding decisions about the selection of public policy and regulatory mechanisms (Freiberg 2010). Australia's political-legal environment is relatively impoverished when it comes to norms, mechanisms and processes, partly because of the absence of an explicit human rights touchstone, like a bill of rights (McNamara 2007). Absent other options, there has been a growing tendency to confront some of the most controversial recent examples of extended criminalisation by pursuing narrow (and rarely successful) constitutional litigation with arguments based on Chapter III of the Australian Constitution and the doctrine of 'institutional integrity' (Ratnapala and Crowe 2012). As the High Court recently observed, this is not an appropriate environment for making value judgments about the propriety of using criminalisation as a public policy tool (Tajjour $v N S W$ at [112]).

Effective pre-enactment scrutiny in the legislative domain is eminently better suited to producing principled criminal law reform than narrow grounds of judicial scrutiny after the event. In theory, parliamentary scrutiny committees and review processes provide a significant opportunity for the invocation of normative principles and for encouraging respect for fundamental principles including the: importance of mens rea in substantive offence definitions; dangers of broadly drawn inchoate offences; risks associated with reverse onus of proof and deeming provisions; dangers of diluting the essentials of procedural justice; and the importance of proportionality, discretion and individualised justice when it comes to sentencing (Brown et al 2015:14-16, 131). Anecdotal evidence suggests that, in practice, scrutiny committees exert little influence on the deployment of criminal law 'solutions' to public policy problems (for a recent example, see Brown and Quilter's (2014) account of the rise and speedy demise of 'quality' bail law reform in NSW in 2014; see also Shearan 2009; Ransley 2008; Copley 2009), but no sustained empirical analysis has been undertaken. This article represents a first step towards filling this gap in the emerging criminalisation literature.

\section{New South Wales Legislation Review Committee}

Parliamentary scrutiny committees exist in various forms in all Australian jurisdictions, with terms of reference established by legislation or parliamentary standing orders. ${ }^{3}$ They typically have a mandate to identify instances in which proposed legislation is likely to impact adversely on 'personal rights and liberties'. The rationale for their existence is that their deliberations, insights and interventions might curb (intended and unintended) infringements of rights and liberties arising from parliamentary law-making. ${ }^{4}$

The functions of the NSW Parliament's Legislation Review Committee with respect to all new bills introduced into the legislature are outlined in s 8A of the Legislation Review Act 1987 (NSW):

3 Human Rights (Parliamentary Scrutiny) Act 2011 (Cth) and Parliament of Australia Senate Standing Order No 24; ACT Legislative Assembly, Resolution of Appointment (27 November 2012) and Human Rights Act 2004 (ACT); Parliamentary Committees Act 2003 (Vic) and Charter of Human Rights and Responsibilities Act 2006 (Vic); Parliament of Queensland Act 2001 (Qld) and Legislative Standards Act 1992 (Qld); Parliamentary Committees Act 1991 (SA); Western Australia Legislative Council Standing Order 25. In Tasmania and the Northern Territory, only regulations are subjected to committee scrutiny: Subordinate Legislation Committee Act 1969 (Tas); Legislative Assembly of the Northern Territory Standing Orders.

4 With reference to the Australian Parliament's Senate Standing Committee for the Scrutiny of Bills, Senator Helen Coonan described the 'double agenda' of scrutiny committees: 'to support the civil rights of citizens' and 'to criticise Parliament, bureaucracies and the executive’ (Coonan and Vanstone 2010). 
(1) The functions of the Committee with respect to Bills are:

(a) to consider any Bill introduced into Parliament, and

(b) to report to both Houses of Parliament as to whether any such Bill, by express words or otherwise:

(i) trespasses unduly on personal rights and liberties, or

(ii) makes rights, liberties or obligations unduly dependent upon insufficiently defined administrative powers, or

(iii)makes rights, liberties or obligations unduly dependent upon non-reviewable decisions, or

(iv) inappropriately delegates legislative powers, or

(v) insufficiently subjects the exercise of legislative power to parliamentary scrutiny.

The phrase 'personal rights and liberties' is the primary touchstone for determining the limits of legitimate law-making under NSW's system of scrutiny. The phrase is a vague one, and its scope is not defined by the Legislation Review Act 1987 (NSW). The Committee has taken the position that the phrase should be interpreted liberally and that a broad range of 'rights' from a variety of sources should be taken into account, including:

- Australian law, especially the common law, NSW statute law and the Australian Constitution;

- international human rights law, especially human rights treaties to which Australia is a party; and

- the law and jurisprudence of other jurisdictions (NSW Legislation Review Committee (nd:[8]).

The Committee's mandate is not limited to criminal law, but covers 'all bills' introduced. The Committee also reviews disallowable regulations (Legislation Review Act 1987 (NSW) s 9). However, some of the most significant threats to 'personal rights and liberties' are raised by criminal law bills. For example, the Committee has identified strict liability criminal offences - where the prosecution is relieved of the burden of having to prove subjective fault beyond reasonable doubt for a particular element of an offence - as deserving close scrutiny (NSW Legislation Review Committee 2006).

Pursuant to the re-establishment of the Committee on 2 June 2015, following the March 2015 Election (Parliament of NSW nd(b)), the Committee currently has eight members drawn from both houses (five from the Legislative Assembly and three from the Legislative Council), including both Government Members of Parliament ('MPs') (five) and Opposition MPs (two), and one Greens MP. Ministers and Parliamentary Secretaries are not eligible to be members of the Committee (Legislation Review Act 1987 (NSW) s 5) - a rule presumably designed to achieve a degree of separation between the Executive and the Legislature (of which the Committee is part) so as to foster greater scope for independent scrutiny. However, under the Legislation Review Act 1987 (NSW) s 8A(2), the Committee has no power to 'veto' a bill or compel amendments: 'A House of Parliament may pass a Bill whether or not the Committee has reported on the Bill, but the Committee is not precluded from making such a report because the Bill has been so passed or has become an Act.'

The Committee has a heavy workload. In 2012, the then Chair of the Committee, Stephen Bromhead, described the Committee as 'the hardest working committee in this Parliament: it delivers the most reports' (New South Wales 2012n). In 2014, it examined 118 bills 
(Parliament of NSW nd(d)). Parliamentary timetables are such that staff, legal advisers and Committee members frequently must complete their reviews very quickly (Shearan 2009).

The Committee's analysis of each bill is presented in a public record, the Legislation Review Digest (see Parliament of NSW nd(c)), which is released periodically throughout the year (approximately 15-20 times annually) and is tabled in both houses of Parliament.

\section{Method}

We examined all criminal law bills introduced into the NSW Parliament in a three-year review period (January 2010 to December 2012). This review period was chosen because it includes periods of Labor Government (up to March 2011) and Coalition Government (from March 2011). Our aim was to evaluate the impact of the NSW Legislation Review Committee as an institutional scrutiny mechanism generally, rather than its performance during a particular period of government. ${ }^{5}$

Our working definition of a 'criminal law bill' is a bill that does one or more of the following:

- creates a new offence or expands an existing offence;

- $\quad$ increases a penalty, establishes a mandatory penalty or changes sentencing laws;

- increases the intrusive powers of police or other state agencies; and/or

- changes the procedures by which criminal offences and allied powers are administered.

This definition includes bills to amend the Crimes Act 1900 (NSW) or other primary criminal law and criminal procedure statutes (for example, the Crimes (Sentencing Procedure) Act 1999 (NSW); Summary Offences Act 1988 (NSW); Firearms Act 1996 (NSW); Drugs Misuse and Trafficking Act 1985 (NSW)), as well as bills to introduce/amend offences, powers and procedures contained in other statutes (such as the National Parks and Wildlife Act 1974 (NSW); Environmental Planning and Assessment Act 1979 (NSW)).

In the three-year period under review, a total of 368 bills were examined by the NSW Legislation Review Committee (including 160 bills in 2010, 87 in 2011, and 121 in 2012). Of this total, 82 bills (22 per cent) fell within our definition of a criminal law bill.

Stage 1 of our study involved reviewing the analysis and commentary contained in the Legislation Review Digests for each of these criminal law bills. Using as our primary touchstone the question of whether the Committee considered that the bill 'trespasses unduly on personal right and liberties' (per s 8A(1)(b)(i) of the Legislation Review Act 1987 (NSW)), we catalogued the Committee's analysis of each bill using 12 categories, including a category of 'no issues' where none were identified by the Committee. The 12 categories were: no issues; strict liability; excessive penalty; mandatory sentence; presumption of innocence; disproportionate impact (on a particular group); procedural fairness; immunity from criminal responsibility; privacy/other liberty issues; freedom of association/expression/religion; illdefined/wide offence or power; and retrospectivity. These categories included terminology expressly and regularly employed by the Committee in the Legislation Review Digests to describe 'Issues Considered' — such as 'strict liability', 'excessive punishment' and

The format of, and level of detail contained in, the Legislation Review Digests changed in 2011 (with the commencement of the $55^{\text {th }}$ Parliament under a Coalition Government). 
'retrospectivity' — as well as aggregate terminology we adapted to facilitate classification and analysis of a range of related issues that were the subject of less frequent comment by the Committee (for example, 'privacy/other liberty issues' and 'ill-defined/wide offence or power').

Stage 2 involved a review of Legislative Assembly and Legislative Council Hansard for each bill using NSW Parliament's online Hansard search facility (Parliament of NSW nd(a)) to determine the extent to which the Committee's commentary was visible or resonated in parliamentary debates. We also compared bills as introduced with bills as enacted to identify any amendments made and upon what basis. Specifically, Legislation Review Committee comments and recommendations were cross-matched to the progress and amendment history (if any) of each bill. By these means we aimed to identify:

- the frequency with which the Committee indicated that a criminal law bill might trespass on personal rights and liberties, and the nature of the issues most commonly raised by the Committee;

- the frequency with which the Committee's analysis was expressly referred to, or was otherwise influential in parliamentary debates, and the types of bills and issues in relation to which the Committee's work was most visible and/or influential; and

- $\quad$ any instances in which the Committee's concerns about potential rights and liberties infringement were remedied by an amendment to the bill in question.

Stage 3 involved closer analysis of illustrative examples regarding the relationship between the Legislation Review Committee's work and how Parliament undertakes its criminal lawmaking function.

\section{Digest analysis}

Table 1 summarises our findings on the frequency with which the Legislation Review Committee raised concerns about 'rights and liberties' infringements. ${ }^{6}$

Possible infringements were the subject of discussion by the Committee for 80 per cent of the criminal law bills examined during the three-year review period. For the remaining 20 per cent of bills, the Committee identified no issues, although our own analysis of these bills suggests that, for a small number of them, 'rights and liberties issues' were potentially raised by the proposed legislation in question. For example, the Committee did not comment on the freedom of association and movement issues raised by the Law Enforcement (Powers and Responsibilities) Amendment (Move on Directions) Bill 2011 (NSW) (Parliament of NSW Legislation Review Committee 2011:68).

The most commonly identified areas of concern were: infringements of privacy or other liberty issues (25 bills); erosion of the presumption of innocence (including reverse onus provisions and limitations on the right against self-incrimination) (22); reductions in procedural fairness (17); and retrospectivity (12).

Where a 'rights and liberties issue' was identified by the Committee, we identified what action it took. Our findings on this question are summarised in Table 2.

\footnotetext{
Note that Table 1 records whether an issue was noted by the Committee, not the frequency with which it was raised in the context of a particular bill. Some bills raised multiple issues or raised the same issue multiple times.
} 
Table 1: Nature of concern raised by committee

\begin{tabular}{|l|c|c|c|c|}
\hline \multicolumn{1}{|c|}{ Issue raised } & 2010 & 2011 & 2012 & $2010-12$ \\
\hline No issues & 8 & 2 & 6 & 16 \\
\hline Strict liability & 5 & 0 & 3 & 8 \\
\hline Excessive punishment & 4 & 0 & 3 & 7 \\
\hline Mandatory sentence & 0 & 1 & 1 & 2 \\
\hline Presumption of innocence & 10 & 2 & 10 & 22 \\
\hline Disproportionate impact & 7 & 0 & 1 & 8 \\
\hline Procedural fairness & 6 & 1 & 10 & 17 \\
\hline Immunity from criminal responsibility & 1 & 0 & 0 & 1 \\
\hline Privacy/other liberty issues & 11 & 3 & 11 & 25 \\
\hline $\begin{array}{l}\text { Freedom of } \\
\text { association/expression/religion }\end{array}$ & 2 & 0 & 5 & 7 \\
\hline Ill-defined/wide offence or power & 2 & 1 & 3 & 6 \\
\hline Retrospectivity & 7 & 0 & 5 & 12 \\
\hline Total & $\mathbf{4 3}$ & $\mathbf{1 0}$ & $\mathbf{2 9}$ & $\mathbf{8 2}$ \\
\hline
\end{tabular}

Table 2: Action taken by Committee

\begin{tabular}{|l|c|c|c|c|}
\hline Year & $\begin{array}{c}\text { Refer to } \\
\text { Parliament }\end{array}$ & $\begin{array}{c}\text { Correspond with } \\
\text { Minister }\end{array}$ & Issue noted & None (no issue) \\
\hline 2010 & 25 & 3 & 16 & 8 \\
\hline 2011 & 4 & 0 & 4 & 2 \\
\hline 2012 & 11 & 0 & 19 & 6 \\
\hline Total & $\mathbf{4 0}$ & $\mathbf{3}$ & $\mathbf{3 9}$ & $\mathbf{1 6}$ \\
\hline
\end{tabular}

Of the 82 criminal law bills reviewed by the Committee over the three-year review period, just under half (49 per cent: 40 bills) were referred to Parliament in relation to one or more issues. In 2010 (but not in 2011 and 2012), the Committee also employed the option of resolving to correspond with the relevant Minister in relation to an issue of potential concern — and did so in relation to three bills.

In relation to 39 bills (48 per cent) the Committee 'noted' one or more issues. In this context, 'noting' means that the Committee considered that a 'rights and liberties' issue arose, but was ultimately satisfied that no further comment, adverse comment or referral to Parliament was required. That is, the Committee made a qualitative assessment of the magnitude of the possible infringement and its acceptability in the context of the objectives underlying the bill, and the bill's anticipated practical operation. A 'right and liberties infringement' might be regarded as 'reasonable in the circumstances', or justified in light of the bill's 'overriding public interest', or acceptable because the bill struck an 'appropriate balance' between competing interests.

For example, in relation to the Work Health and Safety Bill 2011 (NSW), the Committee examined two offence definitions that effected a reversal of the onus of proof and commented: 
The Committee will be concerned where legislation reverses the onus of proof, which is inconsistent with the presumption of innocence.

However, the Committee considers that in certain circumstances it may be appropriate to shift the onus of proof, for example, where knowledge of certain factual circumstances are in the possession of one party. The Committee therefore does not consider the reversal of the onus of proof trespasses on personal rights and liberties (Parliament of NSW Legislation Review Committee 2011:136).

'Noting' and 'referral to Parliament' are not mutually exclusive options in relation to a particular bill; occasionally the Committee referred a bill to Parliament in respect of one issue, and merely noted another issue raised by the same bill.

Our overall assessment, having examined all relevant Legislation Review Digests in the period under review, is that the Committee was thorough in identifying issues of potential concern. In our assessment, the Committee also seemed to generally exercise sound judgment when determining its response to an identified issue - specifically, whether to refer the issue to Parliament or whether to merely note it and express a view as to the acceptability of the bill.

\section{Hansard analysis}

We next examined the evidence as to whether the Legislation Review Committee exerted an influence on the nature, quality and outcomes of parliamentary debates on criminal law bills. The direct visibility of the Committee was assessed, in the first instance, by searching Hansard for express references to the Committee during Legislative Assembly and Legislative Council debates on the 40 criminal law bills during the review period in relation to which the Committee made a reference to Parliament. The possible indirect influence of the Committee's analysis - for example, where an MP's speech on a bill may have been influenced by his or her reading of the relevant Digest, but where the Legislation Review Committee is not expressly acknowledged as a source - is harder to assess. We attempted to detect such traces by conducting keyword searches of Hansard (both Houses) for all debates on referred bills, based on the categories employed to analyse the Legislation Review Digests (see above), noting that this search also captures situations where Members raised rights and liberties issues of their own volition (that is, unprompted by the Committee's work).

Of the 40 criminal law bills in relation to which one or more 'rights and liberties' issues was referred to Parliament by the Committee, the Committee's comments were expressly referred to in only 14 bill debates. In relation to a further eight bills, reference was made to a rights and liberties issue, without reference to the Committee. ${ }^{7}$ There was no reference to the Committee or its concerns in 18 of the 40 criminal law bills examined. This means that for 45 per cent of the bills for which the Committee deemed the potential 'rights and liberties' infringement to be sufficiently serious to warrant a referral to Parliament, no Member of Parliament mentioned the Committee's concerns.

Although it might be considered desirable that Parliament debate the rights and liberties implications of a new criminal law bill every time a matter is referred by the Legislation Review Committee, a 'hit' rate of 55 per cent (which includes both express mention of the Committee and the raising of rights and liberties concerns without mention of the Committee) suggests a not insignificant degree of visibility. However, this figure requires further

It is not possible to determine from Hansard whether the MP in question was motivated to raise a rights and liberties issue in relation to a criminal law bill because he or she had been 'briefed' by the Legislation Review Committee's Digest or whether the comment was independently motivated. 
investigation. To this end, we completed content analysis of the parliamentary debates on the 22 bills in question, with the objective of revealing the nature and quality of MPs' references to the Legislation Review Committee and/or rights and liberties issues.

As anticipated, not all 'mentions' were of the same calibre. We identified several different ways in which Members of Parliament referred to the Legislation Review Committee or otherwise raised rights and liberties issues. In relation to eight of the 22 bills, serious concerns about the infringement of fundamental rights or liberties were raised by a non-Government MP, whether to register an in-principle objection, to explain why an MP/party planned to oppose the legislation, or to call for an amendment to the bill. ${ }^{8}$ In all but two of these cases, it was a Greens MP who raised a substantive objection to the criminal law bill in question. In only one case - the Crimes Amendment (Murder of Police Officers) Bill 2011 (NSW) (discussed further below) - did the Opposition refuse to support a criminal law bill on 'rights and liberties' grounds (in this instance, opposition to mandatory sentencing). On one occasion, it was the Government that announced an amendment based on rights and liberties concerns raised by the Legislation Review Committee (as well as by the Opposition and other stakeholders). This bill — the National Parks and Wildlife Amendment Bill 2010 (NSW) was the only criminal law bill in the review period to have been amended based on rights and liberties/over-criminalisation concerns (and is discussed further below).

On a number of occasions, a 'rights and liberties' issue was raised by an Opposition MP in an attempt to generate dialogue about the merits of the Bill or to solicit a further response from the relevant Minister (see, for example, Credit (Commonwealth Powers) Bill 2010 John O’Dea MLA, Liberal (New South Wales 2010a); Protected Disclosures Amendment (Public Interest Disclosures) Bill 2010 - John Kaye MLC, Greens (New South Wales 2010m); Crimes Legislation Amendment Bill 2012 - Tania Mihailuk MLA, ALP (New South Wales 2012j). Typically, however, such invitations did not trigger a substantive debate of the issue in Parliament, let alone amendment. Government responses in these situations tended to be relatively cursory (see, for example, Credit (Commonwealth Powers) Bill 2010 - Penny Sharpe MLC, ALP (NSW 2010c); Crimes Legislation Amendment Bill 2012 Brad Hazzard MLA, Liberal (NSW 2012k)).

In a small number of cases, a Government Minister or MP initiated the reference to the Legislation Review Committee, but in order to support or justify the content of a bill, rather than to query or signal reconsideration of the bill (see, for example, Court Information Bill 2010 - Kayee Griffin MLC, ALP (NSW 2010h); Law Enforcement (Powers and Responsibilities) Amendment (Kings Cross and Railways Drug Detection) Bill 2012 — Geoff Provest MLA, National (New South Wales 2012l)). Sometimes the Opposition also explained

8 Concerns included: opposition to apparent immunity to casino staff from criminal responsibility in Casino Control Bill 2010 (NSW) — Lee Rhiannon, Greens (New South Wales 2010g); concerns over the introduction of strict liability offences with imprisonment terms in the Credit (Commonwealth Powers) Bill 2010 — John Kaye MLC, Greens (New South Wales 2010b); denial of procedural fairness to those refused firearms licences in the Weapons and Firearms Legislation Amendment Bill 2010 - Lee Rhiannon MLC, Greens (New South Wales 2010j); concerns over strict liability offences, removal of defences and exclusion of appeals and administrative review processes in Water Management Amendment Bill 2010 — Dr Gordon Moyes, Family First (New South Wales 2010n); additional financial penalty in the Classification (Publications, Films and Computer Games) Enforcement Amendment Bill 2010 — David Shoebridge MLC, Greens (New South Wales 2010k); restrictions on freedom of association in the Crimes Amendment (Consorting and Organised Crime) Bill 2012 - Jamie Parker MLA, Greens (New South Wales 2012b); issues over freedom of association and implications for right to work in the Crimes (Criminal Organisations Control) Bill 2012 — Clover Moore MLA, Independent (New South Wales 2012e) and David Shoebridge MLC, Greens (New South Wales 2012f); opposition to mandatory sentencing in the Crimes Amendment (Murder of Police Officers) Bill 2011 — multiple ALP and Green MPs (New South Wales 2011a, 2011b). 
its support for a bill in this way (see Tattoo Parlours Bill 2012 (NSW) - Sophie Cotsis MLC, ALP (New South Wales 2012i)).

Overall, we found little evidence that the work of the Legislation Review Committee enhances the quality of parliamentary debate on criminal law bills. Government and Opposition MPs appear to be very selective and strategic about how and when they make reference to the Legislation Review Committee and rights and liberties concerns. Minor party and Independent MPs, especially Greens MPs, were the most likely to attempt to generate substantive debate and/or amendment by invoking the Legislation Review Committee or otherwise questioning the rights and liberties implications of a criminal law bill. This, however, rarely triggered a sustained or vigorous debate in Parliament.

Another important measure of impact is the outcome of parliamentary processes involving criminal law bills. Table 3 summarises our findings on the fate of criminal laws bills in relation to which the Legislation Review Committee had referred one or more matters to Parliament.

Table 3: Fate of bill

\begin{tabular}{|l|c|c|c|c|}
\hline Year & Bill not passed & $\begin{array}{c}\text { Bill passed without } \\
\text { amendment }\end{array}$ & $\begin{array}{c}\text { Bill passed with } \\
\text { amendment, but } \\
\text { unrelated to LRC } \\
\text { concerns }\end{array}$ & $\begin{array}{c}\text { Bill passed with } \\
\text { amendment in } \\
\text { response to LRC } \\
\text { concerns }\end{array}$ \\
\hline 2010 & 4 & 14 & 6 & 1 \\
\hline 2011 & 0 & 4 & 0 & 0 \\
\hline 2012 & 2 & 7 & 2 & 0 \\
\hline Total & $\mathbf{6}$ & $\mathbf{2 5}$ & $\mathbf{8}$ & $\mathbf{1}$ \\
\hline
\end{tabular}

Table 3 demonstrates that of the 40 bills the subject of a Legislation Review Committee referral during 2010-12, 25 were passed without amendment — and no mention was made in parliamentary debates of the Committee or rights and liberties concerns. Eight bills were passed with amendment, but the amendment did not relate to the concerns raised by the Committee or any other rights and liberties concerns. Six bills were not passed, but not because of rights and liberties concerns. Only one bill was amended in response to rights and liberties concerns that had been identified by the Legislation Review Committee and referred to Parliament: the National Parks and Wildlife Amendment Bill 2010 (NSW). This bill is discussed further below.

\section{Illustrations of the Committee/law-making relationship}

There are three further observations to be made about the relationship between the work of the Legislation Review Committee and how Parliament undertakes its law-making function.

First, at times, the NSW Government's determination to introduce legislation in haste means that the Committee has no opportunity to consider a bill prior to its rushed passage through Parliament. Such situations vividly illustrate a tendency for the politics of 'law and order' to subvert the objective of meaningful scrutiny. The Crimes Amendment (Murder of Police Officers) Bill 2011 (NSW) illustrates this point. This Bill introduced the first mandatory sentence in recent NSW history: life imprisonment for murdering a police officer (Crimes Act 1900 (NSW) s 19B). The period from introduction of the Bill in the Legislative 
Council (26 May 2011) and Assent/commencement (23 June 2011) was less than one month. ${ }^{9}$ The Labor Opposition voted against the Bill.

The Legislation Review Committee did not report on the Bill until its first report for 2011 (8 August), by which time the Bill was fully operational legislation. ${ }^{10}$ In this context, the Committee's decision to refer to Parliament 'the question of whether the imposition of mandatory life sentences ... trespasses unduly on rights and liberties’ (Parliament of NSW Legislation Review Committee 2011:17) was symbolic at best.

Second, and relatedly, another manifestation of the influence of 'law and order' politics in NSW is that, even when the Legislative Review Committee does have the opportunity to consider a bill at length prior to enactment and raises significant rights and liberties concerns, its capacity to influence criminal law-making is confounded by the bipartisanship that frequently surrounds punitive criminalisation directed at 'demonised' targets (Poynting and Morgan 2007; Cohen 1972). This point is powerfully illustrated by the Crimes (Criminal Organisations Control) Bill 2012 (NSW). This Bill was the NSW Parliament's second attempt to introduce control order legislation relating to outlaw motorcycle gangs ('bikies') after the first attempt - the Crimes (Criminal Organisations Control) Act 2009 (NSW) — was found by the High Court to be constitutionally invalid (Wainohu v New South Wales). The Crimes (Criminal Organisations Control) Bill 2012 (NSW), introduced into the Legislative Assembly on 15 February 2012, was a slightly modified version of the 2009 legislation, 'tweaked' to address the flaws identified by the High Court.

At the heart of the control order regime is the pre-emptive criminalisation of association between individuals who are considered to pose a risk of future criminal behaviour (Brown et al 2015:1219-22). Such regimes are controversial crime prevention methods (Ashworth and Zedner 2014), and have been widely criticised for extending the net of criminalisation too far (Cowdery 2009; Loughnan 2009). Unsurprisingly, when the Legislation Review Committee considered the Crimes (Criminal Organisations Control) Bill 2012 (NSW), it identified a range of concerns in terms of the bill's implications for rights and liberties. Noting the impact of the control order on freedom of association, the Committee referred a number of procedural matters to Parliament, including: whether affected persons were given adequate notice and sufficient time to contest a control order application; whether the use of a 'balance of probabilities' standard was appropriate, given that findings of fact that supported the making of an order subsequently exposed individuals to the risk of criminal punishment; and whether a 28-day limit on appeals as of right was appropriate. More substantively, the Committee referred to Parliament the question of 'the appropriateness of interim control orders and control orders as they erode the presumption of innocence by controlling the association of individuals not necessarily found guilty of an offence' (Parliament of NSW Legislation Review Committee 2012:13). The Committee referred to Parliament those parts of the Bill and outlined the consequences of making a control order 'as constituting an undue trespass

9 The Bill was introduced into the Legislative Council on 26 May 2011, passed by that House on 1 June 2011 and introduced into the Legislative Assembly on the same date. It was passed without amendment on 20 June 2011 by the Legislative Assembly and received Assent and commenced on 23 June 2015. The rapid passage of this criminal law bill is not an isolated example. In the wake of the 2005 'Cronulla riots', the Law Enforcement Legislation Amendment (Public Safety) Bill 2005 (NSW) was introduced and passed in a single sitting day (Loughnan 2010). The Crimes and Other Legislation Amendment (Assault and Intoxication) Bill 2014 (NSW), which, among other things, added the new offence of Assault Causing Death (including a mandatory minimum sentence) to the Crimes Act 1900 (NSW) s 25A, was introduced and passed by both houses on 30 January 2014 and became operational the next day (Quilter 2014, 2015).

10 Section 8A(2) of the Legislation Review Act 1987 (NSW) provides that: 'A House of Parliament may pass a Bill whether or not the Committee has reported on the Bill, but the Committee is not precluded from making such a report because the Bill has been so passed or has become an Act.' 
on personal rights and liberties in relation to an individuals' right of freedom of association' (2012:15). The Committee also referred to Parliament those provisions in the Bill that relied on strict liability, as well as the implication for the right to work given the restrictions on employment that would apply to a person who was made the subject of a control order.

Of all the bills reviewed as part of this study, the Crimes (Criminal Organisations Control) Bill 2012 (NSW) was one of the most rigorously examined and scrutinised by the Legislation Review Committee, producing this long list of rights and liberties concerns and associated referrals to Parliament. It would have been reasonable to expect that the Committee's concerns about such an extreme exercise in pre-emptive criminalisation would have been thoroughly aired and addressed during parliamentary debate. The reality was rather different. The only MPs to refer directly to the rights and liberties concerns raised by the Legislation Review Committee were Clover Moore, an Independent in the Legislative Assembly, and David Shoebridge, a Greens Party member in the Legislative Council (and also a member of the Legislation Review Committee). Haste was again an issue. When the Bill was debated in the Legislative Assembly on 15 February 2012, the Legislation Review Committee had not yet tabled its analysis of the Bill. Clover Moore reminded the Assembly that the Committee had previously raised concerns about the predecessor to the 2012 Bill:

I wish to make a brief contribution to what I consider to be a pretty terrible debate. In 2009 I opposed the former Government's introduction of laws to declare certain gangs as criminal and to make a declaration that certain people are members of the gang and cannot associate with each other. I opposed the introduction of those laws. I called a division and I voted on my own. I opposed the legislation because it was rushed through Parliament although it had a serious impact on basic civil rights.

\section{$\cdots$}

[T] he then Legislative Review Committee reported serious concerns about the move away from the presumption of innocence, breaches of the International Covenant on Civil and Political Rights and the failure to exclude organisations such as environment and animal rights groups involved in direct action. This bill is about establishing whether people are criminals and are associated with criminal activity and debate should focus on whether this approach will reduce the criminal activity about which the community is so concerned. I remain uncertain that this bill will reduce crime and I am very disappointed about the processes that have occurred and the manner in which this bill has been summarily pushed through Parliament today (New South Wales 2012e).

No other MP in the Legislative Assembly spoke on the rights and liberties implications of the bill. The Labor Opposition's only mention of rights and liberties came in the form of an attempt by Shadow Attorney General Paul Lynch to ridicule the Attorney General, Greg Smith, for having expressed some concerns about the 2009 version of the control order legislation when in Opposition, which Lynch characterised as a complaint that the legislation 'took away the rights of bikies' (New South Wales 2012c).

Legislative Council debate on the Crimes (Criminal Organisations Control) Bill 2012 (NSW) took place on 14 March 2012, by which time the Legislation Review Committee Digest had been released. Nonetheless, David Shoebridge was the only Member of the Legislative Council ('MLC') to echo the rights and liberties concerns of the Committee:

The Greens oppose the Crimes (Criminal Organisations Control) Bill 2012. It is again notable that on the question of fundamental civil liberties The Greens are the only party that opposes this extraordinary attack on civil liberties. The bill reintroduces previous New South Wales socalled anti-bikie laws, which the High Court quite properly struck down in the middle of last year. The bill is very unlikely to assist in addressing meaningfully the problem of violent 
criminal gangs in New South Wales. However, it will seriously impinge on the rights and freedoms that most of us would expect this Parliament to stand up for in a free and democratic society (New South Wales 2012x).

The only other Member to mention rights and liberties was Liberal MLC David Clarke, who countered that: 'This bill is full of protections for civil liberties and legal rights and human rights' (New South Wales 2012h).

The gulf between the rigour and quality of the Legislation Review Committee's analysis of the Crimes (Criminal Organisations Control) Bill 2012 (NSW) and the nature of parliamentary debate on the bill was vast. The Legislation Review Committee is not a partisan human rights organisation or a self-interested lobby group, but a cross-party committee of members of Parliament. Moreover, as this analysis has shown, the Committee is judicious about when it is necessary, and why it is appropriate, to refer to Parliament a question relating to a bill that comes before it for consideration. That the Committee's views on a bill attract so little attention in Parliament - even in the case of a bill like the Crimes (Criminal Organisations Control) Bill 2012 (NSW), which effected an unprecedented expansion of the parameters of criminalisation in NSW - provides a vivid illustration of our key finding in this article. As currently practised, pre-enactment parliamentary scrutiny is an ineffective mechanism for influencing the quality of criminal law-making in NSW.

In the broader political environment, where neither of the major political parties is prepared to take the risk of being seen as 'soft on crime', rights and liberties-based objections to criminalisation not only fall on deaf ears, but may also be deployed as 'ammunition' in support of the criminal law expansion in question. In the case of the Crimes (Criminal Organisations Control) Bill 2012 (NSW), curtailment of the rights and liberties of the persons most likely to be affected - members of 'outlaw motorcycle gangs' - is not merely an incidental hazard, but the very point of the extended criminalisation (see Jai Rowell MLA (New South Wales 2012d); see also Crimes Amendment (Consorting and Organised Crime) Bill 2012 (NSW) Greg Smith MLA (New South Wales 2012a); Law Enforcement (Powers and Responsibilities) Amendment (Kings Cross and Railways Drug Detection) Bill 2012 (NSW) — Natasha Maclaren-Jones MLC (New South Wales 2012m)).

The third and final point relates to the only bill (out of 40) to be amended in line with concerns raised by the Legislation Review Committee: the National Parks and Wildlife Amendment Bill 2010 (NSW). This was an unusual instance in which there was bipartisan receptiveness to the key concerns raised by the Legislation Review Committee about possible over-criminalisation. It is noteworthy that the expanded criminalisation proposed - via the addition to the National Parks and Wildlife Act 1974 (NSW) of new offences of harming or desecrating items or places of Aboriginal cultural significance - would impact not the usual 'suspect populations' targeted by the criminal law (McConville et al 1991), but farmers, miners and developers. In its consideration of the National Parks and Wildlife Amendment Bill 2010 (NSW), the Legislation Review Committee had observed, among other things, that:

[t]he Committee recognises the seriousness of the offence of harm to Aboriginal places as they are culturally significant sites. The imposition of strict liability with a potential penalty of imprisonment for 2 years will generally be considered as inappropriate especially in the absence of any defences or reasonable excuse. Therefore, the Committee refers this to Parliament to consider whether the proposed [offence] ... may lead to undue trespasses on personal rights and liberties with regard to its strict liability attracting a potential penalty of imprisonment (Parliament of NSW Legislation Review Committee 2010:29). 
In relation to the offence of harming an Aboriginal object, the Committee was satisfied that there was no undue trespass on rights and liberties, given that the offence did not attract a penalty of imprisonment (2010:39). The Committee also referred to Parliament provisions of the bill that would operate retrospectively, as well as provisions that would provide for an 'additional penalty' without setting a maximum penalty (2010:39-40).

In the Legislative Assembly, Michael Richardson, who led for the Coalition Opposition on the bill, quoted at length from submissions by the NSW Farmers Association and the NSW Minerals Council, in which concern was expressed about the alleged harshness of the new criminal offences and penalties. He reported the Minerals Council's view that 'imposing criminal liability in circumstances where a person did not know, or could not know, that they had damaged an Aboriginal object (despite their best endeavours) is inappropriate and goes against the basic legislative principles of fairness and equity' (New South Wales 2010d). He reported the Farmers Association's view that the bill 'will be socially divisive and will impede the development of effective partnerships between farmers and Aboriginals for the protection of Aboriginal places' (New South Wales 2010d).

In announcing that the NSW Government would introduce amendments to the Bill, the then ALP Minister for Climate Change and the Environment, Frank Sartor, recognised that:

Concerns have been raised by various stakeholders that the offences as worded could amount to absolute liability removing the common law defence of honest and reasonable mistake of fact. In response to these concerns, the Government is proposing amendments to make it clear that the offences are strict liability and the common law defence of honest and reasonable mistake of fact still applies (New South Wales 2010e).

See now National Parks and Wildlife Act 1974 (NSW) s 86(2), (4), (5).

The Minister expressly recognised the Legislation Review Committee's concerns regarding retrospectivity and advised that the offending provision would be removed (New South Wales 2010f). The Greens expressed support for the bill in its original unamended form (see New South Wales 2010i).

There is a certain irony in the fact that the only example of the Legislation Review Committee's 'effectiveness' in reining in perceived excesses in a criminal law bill occurred in relation to a bill where the Committee's concerns lined up with those of powerful economic interests and a rarely seen consensus between both sides of politics that the criminal law should not be allowed to fall harshly on (certain) individuals and organisations. This example, ${ }^{11}$ suggests that, rather than being a normative constant, the currency of 'rights and liberties' concerns can be employed selectively and cynically in the law-making process. It may be devalued to the point of invisibility (or worthlessness) or embraced as a constraint on criminalisation where there are powerful interests at stake and lobby groups at work, and where it is considered that there is electoral advantage in protecting rights and liberties. On other occasions, Parliament appears to see electoral appeal in infringing the rights and liberties of 'demonised' targets - like 'outlaw motorcycle gangs' (see, for example, Crimes (Criminal Organisations Control) Act 2012 (NSW); Crimes Amendment (Consorting and Organised Crime) Act 2012 (NSW); Tattoo Parlours Act 2012 (NSW)).

11 See also concerns raised by Russell Turner for protecting the interests of the NSW Division of the Australian Veterinary Association in relation to concerns raised by the Legislative Review Committee about the erosion of the privilege against self-incrimination in the Veterinary Practice Amendment Bill 2010 (NSW) (New South Wales 2010l); and Dr Gordon Moyes (Family First) expressing concerns for the rights of the National Irrigators' Council in relation to the Legislative Review Committee's concerns for strict liability offences, defences and non-reviewable decisions in relation to the Water Management Amendment Bill 2010 (NSW) (New South Wales 2010n). 
All of the three points raised here speak to the entrenched politicisation of criminal lawmaking in NSW. As Brown and Quilter (2014) observed in the context of knee-jerk bail law 'reform' in 2014, the environment is one in which punitive and exclusionary responses dominate, with the result that the potential for the Legislation Review Committee's scrutiny processes to produce better quality criminal law-making is almost never realised. An even more pessimistic take on our findings is that the existence and work of the Committee creates the appearance of genuine pre-enactment scrutiny (as noted above, generally the Committee does engage in high-quality and apolitical analysis of bills of the sort that a law-making process with integrity requires), but the appearance of scrutiny is rendered a facade by routine parliamentary disregard for the Committee's findings and recommendations. The law-making process is rendered 'valid' for having engaged in pre-enactment scrutiny, but via a process that has no impact on outcomes. In this way, and unfortunately, the Legislation Review Committee is implicated in an embedded cycle of law and order law-making. As Quilter noted, the "political reality is that the legislative arm of government is dominated by the executive, meaning that the ultimate power of parliamentary scrutiny committees to influence the shape of new criminal laws is limited' (Quilter 2015:100).

\section{Conclusion}

This article aimed to investigate whether parliamentary scrutiny committees, like the Legislation Review Committee in NSW, play an effective role in curbing the potential excesses of criminal law-making. Our analysis of the work of the NSW Committee over a three-year period suggests that the Committee performs the valuable function of identifying, and bringing to Parliament's attention, aspects of proposed new laws that might extend inappropriately beyond the boundaries of the legitimate deployment of criminalisation as a public policy mechanism. Unfortunately, the Committee's good work achieves only limited visibility in Parliament, and there is little evidence that the quality of parliamentary debate is enhanced. While the Committee's work might usefully inform MPs about bills (Shearan 2009), with the exception of Greens MPs, it rarely animates their contributions. Most significantly, there is no evidence that the Committee has any impact on the outcomes of parliamentary decision-making processes on criminal law bills. The potential of the Legislation Review Committee to exert a positive influence on the parameters of criminalisation will not be achieved unless and until the Parliament corrects an entrenched culture of ignoring and deflecting the Committee's advice. In the absence of a legislative mandate that Parliament must debate matters referred by the Committee, or an obligation on Ministers to respond to matters raised, this state of affairs is unlikely to change. Critics of the appropriate deployment of criminal laws will need to continue to search for other viable mechanisms for producing legislative constraint.

\section{Cases}

Tajjour v NSW [2014] HCA 35 (8 October 2014)

Wainohu v New South Wales (2011) 243 CLR 181 


\section{Legislation}

Charter of Human Rights and Responsibilities Act 2006 (Vic)

Commonwealth of Australia Constitution Act 1900 (Cth) ('Australian Constitution')

Crimes (Criminal Organisations Control) Act 2009 (NSW)

Crimes (Criminal Organisations Control) Act 2012 (NSW)

Crimes (Sentencing Procedure) Act 1999 (NSW)

Crimes Act 1900 (NSW)

Crimes Amendment (Consorting and Organised Crime) Act 2012 (NSW)

Drugs Misuse and Trafficking Act 1985 (NSW)

Environmental Planning and Assessment Act 1979 (NSW)

Firearms Act 1996 (NSW)

Human Rights (Parliamentary Scrutiny) Act 2011 (Cth)

Human Rights Act 2004 (ACT)

Legislation Review Act 1987 (NSW)

Legislative Standards Act 1992 (Qld)

National Parks and Wildlife Act 1974 (NSW)

Parliament of Queensland Act 2001 (Qld)

Parliamentary Committees Act 1991 (SA)

Parliamentary Committees Act 2003 (Vic)

Subordinate Legislation Committee Act 1969 (Tas)

Summary Offences Act 1988 (NSW)

Tattoo Parlours Act 2012 (NSW)

\section{References}

Ashworth A (2000) 'Is the Criminal Law a Lost Cause?', Law Quarterly Review 116, 225-56

Ashworth A (2008) 'Conceptions of Overcriminalisation', Ohio State Journal of Criminal Law 5, 407-25

Ashworth A and Zedner L (2014) Preventive Justice, Oxford University Press

Baker D (2001) The Right Not to be Criminalized: Demarcating Criminal Law's Authority, Ashgate

Brown D (2009) 'History’s Challenge to Criminal Law Theory', Criminal Law and Philosophy 3, 271-87 
Brown D (2013) 'Criminalisation and Normative Theory', Current Issues in Criminal Justice 25(2), $605-25$

Brown D (2015) 'Constituting Physical and Fault Elements: A NSW Case Study' in T Crofts and A Loughnan (eds), Criminalisation and Criminal Responsibility in Australia, Oxford University Press

Brown D and Quilter J (2014) 'Speaking Too Soon: The Sabotage of Bail Reform in NSW', International Journal for Crime, Justice and Social Democracy 3(3), 73-97

Brown D, Farrier D, McNamara L, Steel A, Grewcock M, Quilter J and Schwartz M (2015) Criminal Laws: Materials and Commentary on Criminal Law and Process of New South Wales, $6^{\text {th }}$ ed, Federation Press

Byrnes A (2009) 'The Protection of Human Rights in NSW Through the Parliamentary Process A Review of the Recent Performance of the NSW Parliament's Legislation Review Committee', UNSW Law Research Paper No 2009-43

Chalmers J and Leverick F (2013) 'Tracking the Creation of Criminal Offences', Criminal Law Review 543-60

Chalmers J and Leverick F (2014) 'Quantifying Criminalization' in RA Duff, L Farmer, S Marshall, M Renzo and V Tadros (eds), Criminalization: The Political Morality of the Criminal Law, Oxford University Press

Cohen S (1972) Folk Devils and Moral Panics: The Creation of the Mods and the Rockers, Paladin

Coonan H and Vanstone A (2010) ‘Role and Contribution of Legislative Scrutiny Committees', Papers on Parliament No 54, December 2010 <http://www.aph.gov.au/About_Parliament/Senate/ Research_and_Education/pops/ /link.aspx?_id=2D58C1760CFF4847ADBBD1AF0C17FB79\&_z=z>

Copley J (2009), 'Public Deliberation on Legislation: From Fitzgerald to Facebook and Beyond', Paper presented at the Australia-New Zealand Scrutiny of Legislation Conference: Scrutiny and Accountability in the $21^{\text {st }}$ Century, 6-8 July 2009, Canberra, Australia $<$ http://www.aph.gov.au/ /media/Committees/Senate/sl_conference/papers/copley.pdf>

Cowdery N (2009) 'A Threat to the Rule of Law: The New South Wales Crimes (Criminal Organisations Control) Act 2009', Current Issues in Criminal Justice 21(2), 321-4

Duff RA (2014) 'Towards a Modest Legal Moralism', Criminal Law and Philosophy 8(1), 217-35

Duff RA, Farmer L, Marshall S, Renzo M and Tadros V (eds) (2014) Criminalization: The Political Morality of the Criminal Law, Oxford University Press

Freiberg A (2010) The Tools of Regulation, Federation Press

Hogg R and Brown D (1998) Rethinking Law and Order, Pluto Press

Husak D (2008) Overcriminalization, Oxford University Press

Lacey N (2009) 'Historicising Criminalisation: Conceptual and Empirical Issues', Modern Law Review 72, 936-60

Lacey N (2013) 'The Rule of Law and the Political Economy of Criminalisation: An Agenda for Research', Punishment and Society 15(4), 349-66

Loughnan A (2009) 'The Legislation We Had to Have?: The Crimes (Criminal Organisations Control) Act 2009 (NSW)’, Current Issues in Criminal Justice 20(3), 457-65 
Loughnan A (2010) 'Drink Spiking and Rock Throwing: The Creation and Construction of Criminal Offences in the Current Era', Alternative Law Journal 35(1), 18-21

McConville M, Sanders A and Leng R (1991) The Case for the Prosecution, Routlege

McNamara L (2007) Human Rights Controversies: The Impact of Legal Form, Routledge-Cavendish

McNamara L (2015) 'Criminalisation Research in Australia: Building a Foundation for Normative Theorising and Principled Law Reform' in T Crofts and A Loughnan (eds) (2015) Criminalisation and Criminal Responsibility in Australia, Oxford University Press

McNamara L and Quilter J (2015) 'Public Intoxication in New South Wales: The Contours of Criminalisation', Sydney Law Review 37(1), 1-35

New South Wales (2010a) Parliamentary Debates, Legislative Assembly, 11 March 2010, 21 310-2 (John O’Dea)

New South Wales (2010b) Parliamentary Debates, Legislative Council, 16 March 2010, 21 423-4 (John Kaye)

New South Wales (2010c) Parliamentary Debates, Legislative Council, 17 March 2010, 21515 (Penny Sharpe)

New South Wales (2010d), Parliamentary Debates, Legislative Assembly, 21 April 2010, 22070 (Michael Richardson)

New South Wales (2010e) Parliamentary Debates, Legislative Assembly, 21 April 2010, 22081 (Frank Sartor)

New South Wales (2010f) Parliamentary Debates, Legislative Assembly, 21 April 2010, 22082 (Frank Sartor)

New South Wales (2010g) Parliamentary Debates, Legislative Council, 11 May 2010, 22 319-40 (Lee Rhiannon)

New South Wales (2010h) Parliamentary Debates, Legislative Council, 18 May 2010, 22 806-7 (Kayee Griffin)

New South Wales (2010i) Parliamentary Debates, Legislative Council, 1 June 2010, 23360 (Ian Cohen)

New South Wales (2010j) Parliamentary Debates, Legislative Council, 2 June 2010, 23 525-7 (Lee Rhiannon)

New South Wales (2010k) Parliamentary Debates, Legislative Council, 19 October 2010, 26 171-3 (David Shoebridge)

New South Wales (2010l) Parliamentary Debates, Legislative Assembly, 20 October 2010, 26 495-6 (Russell Turner)

New South Wales (2010m) Parliamentary Debates, Legislative Assembly, 27 October 2010, 26 847-8 (John Kaye)

New South Wales (2010n) Parliamentary Debates, Legislative Assembly, 30 November 2010, 28 475-8 (Gordon Moyes)

New South Wales (2011a) Parliamentary Debates, Legislative Council, 1 June 2011, 1585-1601 (various) 
New South Wales (2011b) Parliamentary Debates, Legislative Assembly, 20 June 2011, 2837-57 (various)

New South Wales (2012a) Parliamentary Debates, Legislative Assembly, 14 February 2012, 8129-32 (Greg Smith)

New South Wales (2012b) Parliamentary Debates, Legislative Assembly, 15 February 2012, 8314-5 (Jamie Parker)

New South Wales (2012c) Parliamentary Debates, Legislative Assembly, 15 February 2012, 8331 (Paul Lynch)

New South Wales (2012d) Parliamentary Debates, Legislative Assembly, 15 February 2012, 8334 (Jai Rowell)

New South Wales (2012e) Parliamentary Debates, Legislative Assembly, 15 February 2012, 8343 (Clover Moore)

New South Wales (2012f) Parliamentary Debates, Legislative Council, 14 March 2012, 9487 (David Shoebridge)

New South Wales (2012g) Parliamentary Debates, Legislative Council, 14 March 2012, 9487-9 (David Shoebridge)

New South Wales (2012h) Parliamentary Debates, Legislative Council, 14 March 2012, 9492 (David Clarke)

New South Wales (2012i) Parliamentary Debates, Legislative Council, 23 May 2012, 11 755-7 (Sophie Cotsis)

New South Wales (2012j) Parliamentary Debates, Legislative Assembly, 11 September 2012, 14936 (Tania Mihailuk)

New South Wales (2012k) Parliamentary Debates, Legislative Assembly, 11 September 2012, 14941 (Brad Hazzard)

New South Wales (2012l) Parliamentary Debates, Legislative Assembly, 16 October 2012, 15 721-2 (Geoff Provest)

New South Wales (2012m) Parliamentary Debates, Legislative Council, 24 October 2012, 16 268-9 (Natasha Maclaren-Jones)

New South Wales (2012n) Parliamentary Debates, Legislative Assembly, 22 November 2012, 17426 (Stephen Bromhead)

Parliament of New South Wales (nd(a)) Advanced Search <https://www.parliament.nsw.gov.au/prod/ web/common.nsf/V3SearchSite?open\&area=Hansard>

Parliament of New South Wales (nd(b)) Legislation Review Committee <http://www.parliament.nsw. gov.au/lrc >

Parliament of New South Wales (nd(c)) Legislation Review Digests < http://www.parliament.nsw. gov.au/lrc/digests>

Parliament of New South Wales (nd(d)) Legislation Review Digests $2014<$ http://www.parliament.nsw. gov.au/prod/parlment/committee.nsf/V3ListDigests?open\&vwcurr=V3LRCDigestsByYr\&yr=2014> 
Parliament of New South Wales Legislation Review Committee (nd) Information Paper: 'Rights and Liberties' Considered by the Legislation Review Committee

Parliament of New South Wales Legislation Review Committee (2006) Strict and Absolute Liability, Discussion Paper No 2

Parliament of NSW Legislation Review Committee (2010) Legislation Review Digest, 2 of 2010, 8 March 2010

Parliament of New South Wales Legislation Review Committee (2011) Legislation Review Digest, Digest 1/55, 8 August 2011

Parliament of New South Wales Legislation Review Committee (2012) Legislation Review Digest, Digest 2/2012, 21 February 2012

Poynting S and Morgan G (eds) (2007) Outrageous! Moral Panics in Australia, ACYS Publishing

Pratt L (2012) 'Political Protections of Fundamental Rights as a Means of Mitigating the Weakness of Legal Protections’, Macquarie Law Journal 10, 77-104

Quilter J (2014) 'One Punch Laws, Mandatory Minimums and “Alcohol-Fuelled” as an Aggravated Factor: Implications for NSW Criminal Law’, International Journal for Crime, Justice and Social Democracy 3(1), 81-106

Quilter J (2015) 'Criminalisation of Alcohol Fuelled Violence: One-Punch Laws' in T Crofts and A Loughnan (eds), Criminalisation and Criminal Responsibility in Australia, Oxford University Press

Quilter J and McNamara L (2013) 'Time to Define "the Cornerstone of Public Order Legislation": The Elements of Offensive Conduct and Language under the Summary Offences Act 1988 (NSW)', University of New South Wales Law Journal 36(2), 534-62

Ransley J (2008) 'Illusions of Reform: Queensland's Legislative Assembly Since Fitzgerald' in N Aroney, S Prasser and J Nethercote (eds), Restraining Elective Dictatorship: The Upper House Solution?, UWA Publishing

Ratnapala S and Crowe J (2012) 'Broadening the Reach of Chapter III: The Institutional Integrity of State Courts and the Constitutional Limits of State Legislative Power', Melbourne University Law Review 36(1), 175-215

Shearan A (2009) 'The Role of the Legislation Review Digest in NSW', Paper presented at the AustraliaNew Zealand Scrutiny of Legislation Conference: Scrutiny and Accountability in the $21^{\text {st }}$ Century, 6-8 July 2009, Canberra, Australia <http://www.aph.gov.au/About_Parliament/Senate/Exhibitions_and_ Conferences/sl_conference/papers/shearan>

Zedner L and Roberts J (eds) (2012) Principles and Values in Criminal Law and Criminal Justice, Oxford University Press 